\title{
DA UTOPIA DE MORE À UTOPIA BRASILEIRA: O QUE SERÁ?
}

\author{
Flávia Moreira Guimarães Pessoa* \\ Glauber Dantas Rebouças*
}

\begin{abstract}
Resumo: O artigo se baseia no livro Utopia, de Thomas More, e ressalta a natureza utópica da Constituição brasileira, com sua ideologia preponderantemente democrática, em conflito com o mainstream econômico atual, o neoliberalismo, e os valores (ou desvalores) a ele subjacentes. Abordar-se-ão as noções de utopia e distopia, na Literatura e no Direito Constitucional, com ênfase na axiologia estabelecida na Carta Política brasileira. Também serão elencados exemplos de ideais e comportamentos distópicos verificáveis no Brasil e no mundo, e qual deve ser a postura do jurista frente a essas condutas que se mostram diametralmente opostas aos postulados do Welfare State.
\end{abstract}

Palavras-chave: Utopia. Distopia. Neoliberalismo. Constituição. Democracia.

\section{FROM MORE'S UTOPIA TO BRAZILIAN'S UTOPIA: WHAT WILL IT BE?}

\begin{abstract}
The article is based on Thomas More's Utopia, and highlights the utopian nature of the Brazilian Constitution, with its predominantly democratic ideology, in conflict with the current economic mainstream, neoliberalism, and the values (or devalues) underlying it. The notions of utopia and dystopia will be approached in Literature and Constitutional Law, with emphasis on the axiology established in the Brazilian Constitution. Examples of ideals and dystopic behaviors verifiable in Brazil and in the world will also be listed, and what should be the position of the jurist in face of these behaviors that are diametrically opposed to the Welfare State postulates.
\end{abstract}

Keywords: Utopia. Dystopia. Neoliberalism. Constitution. Democracy.

\footnotetext{
${ }^{*}$ Professora Associada da Universidade Federal de Sergipe (UFS) e da Universidade Tiradentes (UNIT), Juíza do Trabalho (TRT 20 Região), Pós-doutora em Direito do Trabalho pela UFBA, 2016. Doutora em Direito Público pela UFBA, 2008. Mestre em Direito, Estado e Cidadania pela UGF, 2004. Líder do grupo de pesquisa "Hermenêutica Constitucional Concretizadora dos Direitos Fundamentais e Reflexos nas Relações Sociais" da Universidade Federal de Sergipe. Endereço postal: Avenida Marechal Rondon, s/n. ${ }^{\circ}$, Jardim Rosa Elze, São Cristóvão-Sergipe, CEP: 49.100-000. Endereço eletrônico: flaviampessoa@gmail.com

* Juiz de Direito do Tribunal de Justiça do Estado de Sergipe. Graduado em Direito pela Universidade Federal da Bahia. Especialista em Direito Processual Civil pela UNISUL-SC. Mestrando em Direito pela Universidade Federal de Sergipe. Endereço postal: Rua João Mota dos Santos, n. ${ }^{\circ}$ 950, Condomínio Reserva Aruanã, casa 49, Aracaju-Sergipe, CEP: 49.004-021. Endereço eletrônico: gladantas2013@gmail.com
} 


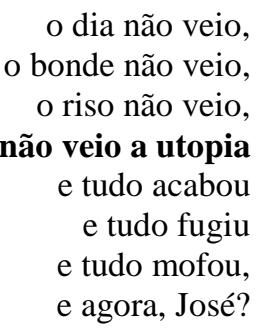

(ANDRADE, 2012, p. 22, grifo nosso)

\section{INTRODUÇÃO}

A Constituição da República Federativa do Brasil veiculou inúmeros valores derivados de uma filosofia humanista, tais como: Democracia, Liberdade, Bem-Estar, Igualdade, Justiça, Fraternidade e Dignidade (CRFB, Preâmbulo e art. 1. ${ }^{\circ}$ ). Elencados dentre os objetivos da República Federativa do Brasil, encontram-se: a construção de uma sociedade livre, justa e solidária; a garantia do desenvolvimento nacional; a erradição da pobreza e da marginalização; e a redução das desigualdades sociais e regionais (CRFB, art. $\left.3 .^{\circ}\right)$.

Não obstante essa direção constitucional no sentido da conformação de uma sociedade igualitária e que preserve os direitos à vida, à saúde, à liberdade, à segurança (CRFB, art. 5. ${ }^{\circ}$, caput), o que se vê, passados trinta anos da promulgação da Constituição, é um Brasil de extremas e profundas desigualdades; nas redes sociais prepondera o hate speech; o país está dentre os com maior número de homicídios do mundo; e a quantidade de dinheiro público desviado pela corrupção alcança índices muito acima da escala global.

Nota-se, então, uma distância abissal entre a utopia constitucional e a realidade distópica brasileira, salientando-se que os dilemas enfrentados pelo Brasil são reflexos da tensão verificável na relação entre os diplomas constitucionais de outros Estados, inclusive aqueles em que se faz presente o constitucionalismo multinível (a exemplo da União Europeia), e as pressões econômico-financeiras internacionais.

Utopia, palavra originariamente cunhada por Thomas More, é considerada polissêmica, sendo objeto de análise da Teoria Literária, da Filosofia, da Sociologia e do Direito, especificamente do Direito Constitucional. No âmbito da Filosofia, inclusive, há o reconhecimento de sua ambiguidade, ou seja: uma vertente positiva, de um vir-a-ser, de 
uma proposta; e seu aspecto negativo, como um ideal esquizofrênico, dissociado da realidade.

No Direito Constitucional, alguns doutrinadores admitem o caráter utópico (positivo) das normas constitucionais, a exemplo de Peter Häberle, Miguel Carbonell, Gomes Canotilho, Jorge Miranda e Paulo Ferreira da Cunha, muito provavelmente em razão do princípio hesseniano da força normativa da Constituição, e sua teleologia, de conformar a sociedade aos valores constitucionalmente estabelecidos.

Ocorre que a globalização e seu corolário econômico, o neoliberalismo, em conjunto com a liquidez de nossa sociedade, como asseverou Bauman (2017), trazem consigo um ideário muitas vezes frontalmente antagônico aos mandamentos constitucionais de dignidade humana, solidariedade e fraternidade, dando azo a uma realidade social tendente à distopia, caracterizada pelo totalitarismo de ideias e pela anulação da intersubjetividade.

O mainstream neoliberal defende, especialmente no aspecto econômico, o rompimento das barreiras entre as nações, o consumismo desenfreado, a massificação da produção e a relativização dos direitos trabalhistas, trazendo como consequências, no âmbito das relações humanas, o desespero do desemprego, um individualismo exacerbado e uma alienação acerca das condições sociais circundantes. Na esfera das políticas estatais, o neoliberalismo apregoa a privatização dos serviços de saúde, educação e previdência social, já que o Estado deve concentrar seus gastos na segurança interna e externa (para manter os excluídos sob controle), e no desenvolvimento de infraestrutura para escoar a produção e permitir o livre comércio.

No presente trabalho, assim, pretender-se-á, pelo método dedutivo, a partir de pesquisa bibliográfica, desvendar os conceitos de utopia - com foco no livro de Thomas More, distopia e ideias correlatas ou alternativas (heterotopia e retrotopia), à luz da Teoria Literária, da Filosofia e do Direito Constitucional, trazendo exemplos de postulados e comportamentos distópicos, no Brasil e no mundo, e qual deve ser a posição do jurista, tendo em vista que o quadro de distopia verificável na sociedade não se encaixa na moldura constitucional.

\section{UTOPIAS}


O termo utopia foi criado por Thomas More, no livro homônimo, publicado em 1516. Na Teoria Literária, Vilas-Boas (2002, p. 95) traça um retrato das utopias, distopias e heterotopias na literatura de expressão alemã, salientando que as utopias são sempre projeções num não lugar, sendo, geralmente, uma impossibilidade. Além da própria obra pioneira de Thomas More, podem ser citados como produções utópicas A Cidade do Sol, de Tommaso Campanella, 1602, e A Nova Atlântida, de Francis Bacon, em 1627 (MATOS, 2017, p. 176-177).

Matos (2017, p. 175) faz um apanhado de obras filosóficas e literárias com objetivos diversos, os quais segundo o autor, foram condensadas por Thomas More no livro de 1516:

\begin{abstract}
As estratégias para se alcançar a efeméride são várias: desde a proposta de um novo sistema social (A República, O Manifesto do Partido Comunista), passando pela transubstanciação de uma língua (Ulisses, $O$ Aleph), chegando até à criação de um mundo outro e diferente ( $O$ Dicionário Kazar, $O$ homem do castelo alto) ou, talvez, fazer isso de uma só vez e, melhor ainda, inventar uma palavra para condensar tudo: foi o que fez Thomas More ao cunhar um dos termos mais ricos, debatidos e controversos desses 500 anos que esta bela edição comemora.
\end{abstract}

Hilário (2013) esclarece que a utopia é, ao mesmo tempo, um gênero literário, consistente em uma narrativa sobre a sociedade perfeita e feliz, e, concomitantemente, um discurso político, que procura expor a cidade justa. Pavliski (2014), por sua vez, indo além da divisão tradicional da utopia como gênero literário e elemento do discurso político, aponta a tese de que a utopia é, antes de tudo, um posicionamento crítico diante da realidade, o qual pode ou não vir a traduzir-se em obra filosófica, sociológica ou literária.

Ricoeur (2015, p. 10), após sublinhar que a utopia e a ideologia revelam pontos de intersecção, reforça que "ambos são fenônemos ambíguos, eminentemente situados". No dizer do autor:

Cada um deles tem um lado negativo e um lado positivo, um papel construtivo e um papel destruidor, uma dimensão constitutiva e uma dimensão patológica. O segundo traço comum é que, dos dois lados, o aspecto patológico aparece de saída, o que faz com que devamos proceder de maneira regressiva, partindo da superfície das coisas. (...) Do mesmo modo, o conceito de utopia goza frequentemente de má reputação. É considerado representante de uma espécie de sonho social que não se preocupa com as etapas reais e necessárias à construção de uma nova sociedade. A visão utópica é frequentemente tratada como um tipo de atitude esquizofrênica perante a sociedade: uma maneira de escapar à lógica da ação por meio de uma construção exterior à história e, ao 
mesmo tempo, uma forma de proteção contra toda espécie de verificação levada a cabo por meio de uma ação concreta (RICOEUR, 2015, p. 10-11).

Citando Karl Mannheim, Ricoeur aponta que a utopia (assim como a ideologia) é um fenômeno desviante em relação à realidade. Interessantíssima é a constatação de Ricoeur (2013, p. 11) para quem "a imaginação social é constitutiva da realidade social". Aqui, observa-se a vinculação da utopia com o imaginário, e este como constitutivo da realidade. Não a constituição pela linguagem (pertencente ao campo simbólico - a palavra, a lei), muito menos pelo real, mas sim a constituição pelo imaginário - campo da produção cultural, como a poesia, e também das ilusões do eu e da alienação, sob o ponto de vista lacaniano, como esclarecem Roudinesco e Plon (1998, p. 371).

No ponto, há plena coincidência entre a enunciação de Ricoeur e o pensamento de Peter Häberle que, em entrevista concedida a Héctor López Bofill (VALADÉS, 2009, p. 182-195), afirma que os produtos culturais clássicos desempenham uma dupla função: de crítica ao Estado constitucional, ao conceito de democracia ou de Estado de Direito (à Berltod Brecht: “todo poder do Estado emana do povo, mas até onde vai?"); e como fonte de legitimação (mencionando o Dom Carlos, de Schiller, e a tensão entre liberdade originária e liberdade outorgada). Nas palavras de Häberle (VALADÉS, 2009, p. 183184):

Há aspectos do direito constitucional que são especialmente sensíveis à
atividade criadora dos poetas. O preâmbulo das constituições é um bom
exemplo, bem como os enunciados empregados nos catálogos dos direitos. Os
poetas proporcionam a suficiente dose de utopia que orienta o sentido da
realidade constitucional. Poder-se-ia citar o caso da nova Constituição Federal
suíça de 1999, uma parte de cujo preâmbulo foi concebida pelo poeta suíço A.
Mushg ao proclamar que a força do povo se mede no bem-estar dos débeis. Os
valores de alguns princípios e objetivos constitucionais, como a tolerância e a
educação democrática, podem fundar-se na formulação lingüística e no
conteúdo material enunciado pelos poetas. No que concerne aos direitos
fundamentais, só haveria de referir-se à Declaração de Direitos do Homem e
do Cidadão de 1789 , cujo sucesso universal foi em parte propiciada pelo
caráter contundente, sugestivo e penetrante do estilo que lhe conferiram alguns
dos literatos reunidos na Assembléia Nacional francesa como Mirabeau.

Ou seja, Häberle associa a poesia à utopia, e essas aos enunciados das constituições e declarações de direitos internacionais. Abrindo parênteses, Häberle (VALADÉS, 2009, p. 185-186) liga a indeterminação própria da poesia (o que possibilita abertura e transformação de sentido) à indeterminação dos dispositivos constitucionais. Isso, segundo ele, explica a peculiaridade dos métodos interpretativos desenvolvidos no âmbito do Direito Constitucional, como a tópica e a interpretação da sociedade aberta de 
intérpretes constitucionais (HÄBERLE, 2002). E cita Schleiermacher e Gadamer, no sentido de a poesia ser um marco de pré-compreensão na arte da interpretação jurídica.

Retomando a divisão entre a utopia política e a literária, Matos (2017, p. 176) esclarece que "o utopista político sempre se refere ao melhor mundo realizável, e não ao melhor mundo fantasiosamente pensável, como os literatos". As utopias políticas, dessa forma, para Matos, constituiriam uma aposta no poder da razão que, aliada à ideia de progresso, típica do Iluminismo, seria capaz de garantir às sociedades humanas formas mais justas de organização social. Recorde-se que o lema da bandeira brasileira é “Ordem e Progresso", perfeitamente inserido na utopia positivista vigente na época em que foi elaborado. Aliás, para Comte, cabia à utopia a tarefa de melhorar as instituições políticas e de desenvolver as ideias científicas (ABBAGNANO, 2012, p. 1173).

Abbagnano (2012, p. 1174) cita como Horkheimer e Marcuse vislumbraram a relação entre utopia e Filosofia. O primeiro definiu a utopia como "a crítica do que é e a representação do que deveria ser"; já Marcuse associou a utopia ao ausente, ao "Outro" (como ideal utópico de uma dimensão de ser), salientando que "O ausente deve estar presente, visto que a maior parte da verdade reside no ausente". Ora, a se aceitar a tese de Horkheimer, reforça-se o quanto o Direito, com sua lógica do dever-ser (pelo menos desde Kelsen) se aproxima da utopia. A adoção da visão de Marcuse aproxima-se da atribuição de um efeito constituinte à utopia, enquanto campo do imaginário, conforme ressaltado por Ricoeur. Sem a arte, os sonhos, as sublimações (para se utilizar a linguagem de Freud) ou o ser humano submerge no real ("psicotizando-se"), ou se torna um neurótico autômato, apático, escravo das circunstâncias. Como disse Matos (2017, p. 180):

Talvez mais grave do que perdermos a capacidade de sonhar é perdermos também a capacidade criativa, mesmo nos pesadelos. Somos obrigados a encarar as nossas próprias sociedades corruptas e desumanizadas em um espelho - deformador, é verdade - que, ao fim e ao cabo, apenas nos mostra a que ponto chegaremos.

Em resumo, ao termo utopia são aplicados sentidos distintos e equívocos entre si, motivo pelo qual se adota uma posição mais restritiva, voltada à sua origem na obra de Thomas More, literalmente significando um não-lugar (embora se admita uma variante minoritária: eu-topia, lugar feliz). Por se tratar de um não-lugar, e como a existência pressupõe um tempo e um espaço definidos, a utopia não pode ser considerada um 
conceito relacionado ao presente, mas sim um vir-a-ser. Sob essa ótica, talvez se assemelhe à retrotopia, de Bauman (2017), esta, porém, voltada para o passado, à nostalgia. Diferentemente, como se verá, da heterotopia (outro lugar) e da distopia (lugar distorcido), as quais podem ser vinculadas ao presente.

O ponto em comum entre todas (utopia, retrotopia, heterotopia) é a busca incessante do ser humano por um ponto de equilíbrio, a quintessência entre seus impulsos egoísticos (que dominam o agora) e a necessidade de sacríficios mútuos em prol do convívio social pacífico (até mesmo como assunção de responsabilidades para com as gerações futuras), evitando-se, concomitantemente, a exacerbação para a distopia.

\section{A UTOPIA DE THOMAS MORE}

Para fins metodológicos, necessário se faz restringir o âmbito de investigação, escolhendo-se, como objeto primordial, o livro que deu à luz o termo Utopia. Trata-se, consoante Pavliski (2014) de uma obra de ficção, dissimulada como uma narrativa de viagem, em que o autor, por meio do navegador português Rafael Hitlodeu, descreve o período em que permaneceu na ilha de Utopia.

Um ponto curioso é que um português narra a sociedade utópica. A utopia, por sua vez, tem uma função constitutiva, na visão de Ricoeur. O livro de Thomas More influenciou, sobremaneira, os Iluministas e estes, junto com o autor inglês, serviram de base ao socialismo utópico de Proudhon, Saint-Simon, Charles Fourier, Louis Blanc e Robert Owen. Foi a partir de críticas ao socialismo utópico que Karl Marx e Friedrich Engels desenvolveram o socialismo científico. Os socialismos científico e utópico foram estudados pela Escola de Frankfurt (dentre outros, de Adorno e Habermas). A Escola de Frankfurt compôs uma das fontes do pensamento dos constitucionalistas portugueses (v.g., Gomes Canotilho e Jorge Miranda) cuja doutrina foi utilizada na elaboração da Constituição portuguesa de 1976. A Constituição brasileira de 1988 se inspirou na Constituição de Portugal, e nos ensinamentos dos referidos constitucionalistas patrícios. Eis, em breve síntese, como a história do pensamento demonstra a origem de muitos dos valores constitucionalmente assegurados, assim como a necessidade de conhecê-los e defendê-los. 
A associação da Ilha de Utopia ao Brasil, além da origem portuguesa dos que as "descobriram" (salientando que um dos primeiros nomes dados às terras brasileiras, quando os navegadores lusitanos aqui aportaram, foi “Ilha de Santa Cruz"), pode ser extraída do período em que ambos os relatos foram divulgados (Brasil - 1500; Utopia 1516). O caráter utópico do País foi reforçado pelo escritor Stefan Zweig, em seu livro Brasil, País do Futuro, em que destaca as potencialidades da nação brasileira. A Carta Política brasileira de 1988, com seu extenso rol de direitos fundamentais e minuciosas normas programáticas (em contraste com a realidade de miséria de muitos, de indiferença da maioria e do luxo de poucos), consolida a identidade entre esse eterno porvir (próprio das utopias) e o Brasil.

Logo no início da narrativa, More aponta, como causa da miséria dos camponeses ingleses, que os levava à criminalidade famélica, "o luxo inconveniente" das demais classes sociais, vestindo-se de forma insolente e com extraordinário luxo na alimentação, e a "grilagem" de terras pelos nobres. Também o germe de uma proposta de distribuição de renda, em lugar de sua concentração, pode ser encontrado na exortação: "Refreai a ganância dos ricos, coibindo o exercício do monopólio" (More, 2017, p. 92). No Brasil, medidas tributárias poderiam ser adotadas para viabilizar essa distribuição de renda, permitindo uma maior inclusão social, tais como: a instituição (prevista constitucionalmente - art. 153, VII) do imposto sobre grandes fortunas; a correção da tabela do imposto sobre a renda (defasada, e sem cumprir sua função progressiva); a atualização da base de cálculo do imposto territorial rural; e o aumento da alíquota do imposto sobre transmissão causa mortis.

Uma crítica ao sistema de ensino jurídico que se repete até a atualidade (focado na memorização de dispositivos legais e precedentes judiciais, em detrimento do desenvolvimento de potencialidades humanísticas e capacidades intelectuais) pode ser encontrada na seguinte descrição de um jurista que debatia com Rafael Hitlodeu: “(...) aquele jurisconsulto se preparava para falar, e decidira fazê-lo naquele modo solene dos argumentadores, que mais diligentemente repetem do que respondem" (MORE, 2017, p. 92).

A multiplicidade de leis e sua absoluta ineficácia é alvo do repúdio de More (2017, p. 105), observando-se uma realidade muito semelhante ao Brasil da atualidade, em que 
o número de textos legais é absurdamente elevado, o que, porém, não corresponde a uma pacificação social efetiva, haja vista a exorbitante quantidade de demandas ajuizadas anualmente perante o Poder Judiciário. Tal paradoxo leva ao questionamento de que até que ponto o próprio sistema jurídico não é uma causa de conflitos sociais, ou mesmo um dos elementos fomentadores da distopia social reinante na atualidade.

O visionarismo de More (2017) atingiu diversos ramos do Direito e reforçou ou antecipou inúmeros postulados filosóficos, podendo-se citar: a necessidade de uma regulamentação de jornada de trabalho (2017, p. 113); a felicidade da vida consubstanciada na fruição de horas de lazer e dedicadas às artes (MORE, 2017, p. 117); o acesso à saúde universal e gratuito (MORE, 2017, p. 118); a já mencionada distribuição de renda (minudenciada às p. 121-125); a importância da educação para o desenvolvimento social (MORE, 2017, p. 125-135); a ética da alteridade (MORE, 2017, p. 127-128); a defesa da eutanásia (MORE, 2017, p. 136); a dignidade dos deficientes intelectuais ou mentais (MORE, 2017, p. 138); a crítica à seletividade inerente ao sistema de justiça (MORE, 2017, p. 140); o pluralismo religioso (MORE, 2017, p. 147-157); a paridade entre aposentados e trabalhadores na ativa e o assistencialismo social (MORE, 2017, p. 157-158).

Atualíssima, e plenamente aplicável à sociedade brasileira, é a citação seguinte, em que Thomas More critica, duramente, a utilização das leis e da administração da coisa pública em prol de privilegiados:

\footnotetext{
Por isso, quando observo e me ocupo de todas essas repúblicas que hoje florescem, e, que Deus me perdoe, não vejo nada além que uma conspiração de ricos, que, em nome da república, tratam de seus interesses. Inventam e excogitam todas as maneiras e artifícios, por meio dos quais, primeiro, sem medo de perder, conservem tudo aquilo que adquiriram dolosamente, e, depois disso, apoderam-se do trabalho de todos os pobres, pagando-lhes pelo trabalho o mínimo possível. Essas maquinações, que os ricos decretaram que fossem observadas em nome do público, isso é, também em nome dos pobres, tornamse leis. (MORE, 2017, p. 158-159).
}

Não há como não fazer uma referência direta ao último REFIS, que reduziu, consideravelmente, as dívidas de sociedades empresárias multimilionárias, à reforma trabalhista, ao uso do BNDES por pessoas físicas e jurídicas, ao Plano Safra. O dinheiro para financiar tudo isso foi retirado (ou deixou de ser aplicado) dos direitos sociais. São maquinações, que, em nome dos pobres, tornam-se leis. A democracia representativa, assim, longe de representar os interesses da maioria da população, e principalmente dos 
economicamente mais vulneráveis, mostra-se a serviço de satisfazer as pretensões de seus próprios componentes, ou dos interesses daqueles que financiam suas eleições.

A edição comemorativa do livro de Thomas More, que serviu como consulta ao presente trabalho, traz ainda uma carta de Guillaume Budé (um dos fundadores do Collège de France e da Bibliothèque Nationale), em que ele apresenta o que talvez venha a ser posteriormente desenvolvido por Häberle (2002) na necessidade de uma abertura da interpretação constitucional, uma crítica à interpretação fechada acerca do Direito pelos denominados jurisconsultos. Eis as palavras de Budé:

Isso acontece sobretudo nos países nos quais os Direitos, que são chamados de
Civil e Canônico, têm grande autoridade nas duas esferas de jurisdição. É
evidente que, por seus costumes e instituições, estabeleceu-se a opinião de que
apenas os homens instruídos nas artes, ou melhor, nas artimanhas do Direito,
que tramam armadilhas para os cidadãos não instruídos e expertos das formulas
legais, isto é, dos enganos, conhecedores de uma justiça pervertida, urdidores
litígios, jurisconsultos de um Direito cruel e invertido, apenas esses podem ser
considerados sumo sacerdotes da Justiça e da equidade, que apenas eles são
dignos de dizer o que é bom e justo, e que ainda têm (o que é uma questão
muito mais importante) a autoridade e o poder de decidir o que cabe a cada um
e o que não cabe, e em que quantidade e por quanto tempo. (MORE, 2017, p.
167).

Se, naquela época, poder-se-ia questionar a legitimidade das fontes do Direito, no que concerne à consagração de desigualdades brutais entre as pessoas (a escravidão era considerada legítima pelo Direito Romano e pelo Direito Canônico) e à sua interpretação conforme os interesses circunstanciais predominantes, atualmente, o catálogo de dispositivos constitucionais e convencionais relativos aos direitos fundamentais é bastante abrangente e generoso. O que se há de perquirir é a sua efetividade (BOBBIO, 2004, p. 230). Para assegurar a máxima eficácia dos direitos humanos, aqueles que compõem os Tribunais Constitucionais (e, quiçá, o Tribunal Constitucional Internacional, se um dia vier a ser instituído) devem incorporar um espírito de vontade constitucional, evitando, não obstante, descambar para um ativismo inconsequente.

\section{DISTOPIAS}

Ensina Matos $(2017,176)$ que o prefixo grego dys (dus-) pode ser traduzido como "doente", "mal" e "anormal"; topos, como visto anteriormente, também de origem grega, significa "lugar". Distopia seria, deste modo, um lugar distorcido ou "um curso anormal e inesperado de acontecimentos que compõem determinada forma social” (HILÁRIO, 
2013, p. 205-206). Matos (2017, p. 176-177) cita François Ost que, a partir de sua análise das fontes do imaginário jurídico contidas nas obras de Franz Kafka, sugeriu serem as distopias "utopias às avessas", i.é, más utopias, sociedades imaginárias nas quais as condições de vida seriam piores que aquelas vivenciadas na realidade. Também no texto de Matos (2017, p. 177) menciona-se que o primeiro registro do termo distopia se deu em um discurso proferido por Greg Webber e John Stuart Mill, no Parlamento Britânico, em 1868.

Hilário $(2013,202)$ aponta a importância que a Escola de Frankfurt dedicou à literatura, como capaz de produzir efeitos de análise acerca das mutações sociais e suas incidências sobre os campos da subjetividade, da política e da ética. Deste modo, como afirma Hilário:

O romance distópico pode então ser compreendido enquanto aviso de incêndio, o qual, como todo recurso de emergência, busca chamar a atenção para que o acontecimento perigoso seja controlado, e seus efeitos, embora já em curso, sejam inibidos (HILÁRIO, 2013, p. 202).

Lapidares são as seguintes palavras de Hilário (2013, p. 205), acerca da relação entre distopias e utopias:

O objetivo das distopias é analisar as sombras produzidas pelas luzes utópicas, as quais iluminam completamente o presente na mesma medida em que ofuscam o futuro. Elas não possuem um fundamento normativo, mas detêm um horizonte ético-político que lhes permite produzir efeitos de análise sobre a sociedade. As distopias ou as utopias negativas "expressam o sentimento de impotência e desesperança do homem moderno assim como as utopias antigas expressavam o sentimento de autoconfiança e esperança do homem pósmedieval" (FROMM, 2009, p. 269).

Terrível, por sua vez, é a função do Direito nas distopias literárias, marcada pela tecnocracia e voltada à preservação da ordem social sufocante da Liberdade, em que os direitos fundamentais são fundamentalmente abolidos. No discurso de O'Brien, no livro 1984, de George Orwell, preludia-se a sociedade que se estava delineando, em que "Não haverá nem arte, nem literatura, nem ciência"(...) e "Se queres uma imagem do futuro, pensa numa bota pisando um rosto humano, para sempre” (MATOS, 2017, p. 177-178). O próprio Matos observa que é tênue a linha que separa a utopia da distopia, posto que, em seu dna, a utopia tem um quê de conformadora.

É como se a distopia fosse o Duplo da utopia - na linha de Otto Rank: aquele que representa as "sombras", o lado obscuro de uma pessoa. Konrad Hesse, ao defender a força normativa da Constituição, pregava que as normas constitucionais teriam a função 
de conformar a sociedade. Também é oportuno registrar que Thomas More foi inclusive consagrado Santo, pela Igreja Católica, sabendo-se que as religiões, de uma forma geral, possuem a finalidade de "salvação" do ser humano, ou pelo menos seu aprimoramento, sendo que a própria ideia de prisão (cela), como local de expiação, tem origem religiosa.

Noutras palavras, as utopias trazem um risco de se transformarem, se os ideiais não forem bem aplicados, em distopias. Popper (apud ABBAGNANO, 1174), por exemplo, viu na utopia uma forma de absolutismo teórico destinado a traduzir-se numa forma de absolutismo prático, ou seja, um plano de transformação social que, para ser completa, tende a produzir, por sua própria constituição, fanatismo e violência. Isso, porém, não significa que se perca a esperança de que os Direitos consagrados na Declaração Universal dos Direitos do Homem ou na Constituição brasileira se tornem realidade.

Nesse sentido, das utopias como prenúncios de um futuro melhor, e das distopias como realidades totalitárias e sufocantes da identidade e das liberdades humanas, além da esperança que se deve ter em relação à concretização das utopias constitucionais, Peter Häberle:

\begin{abstract}
Poder-se-ia dizer que os artistas, por causa de sua sensibilidade e de suas experiências, possuem um olhar em direção ao futuro, ninguém como Shakespeare ou Goethe soube descrever os caracteres e inquietudes que hoje impregnam o homem contemporâneo. Essa vocação profética de alguns artistas possui, em sua vertente pessimista, a faculdade de anunciar-nos realidades sinistras: Kafka ou Orwell acometeram a descrição de um mundo de pesadelo que, posteriormente, se transformou em triste realidade, como sucedeu com a RDA. Eles prognosticaram como uma ordem constitucional pode degenerar em tirania. $\mathrm{O}$ reverso encarnam aqueles autores que nos legaram previsões otimistas sobre as formas de organização humana e que confiavam num furturo livre. Tenho falado frequentemente do irrenunciável quantum de utopia que deve impregnar o Estado constitucional e que foi tradicionalmente mencionado por alguns poetas. Inclusive se pode acrescentar que algumas das utopias enunciadas pelos artistas em seu tempo são hoje realidades no Estado constitucional. (VALADÉS, 2009, p. 189).
\end{abstract}

Atualmente, pode-se dizer que há um “desassossego" (Fernando Pessoa) pairando sobre o pensamento dos juristas, especialmente os constitucionalistas. É que, no Brasil e no mundo, veem-se notícias de comportamentos distópicos, ou seja, que, ao invés de objetivar a Dignidade Humana e todos os valores correlatos (Liberdade, Igualdade, Solidariedade, Fraternidade), demonstram, em alto grau, a fragmentação das pessoas. Trata-se de um lugar ruim e desviante, dos rumos pregados pelos ideais Iluministas de 
convivência harmônica entre os povos e de respeito ao ser humano, como fim em si mesmo.

Foi notícia internacional o caso de Armin Meiwes, conhecido como "O Mestre Açougueiro" ou "Canibal de Rotemburgo". Meiwes publicou um anúncio no site The Cannibal Cafe, procurando "uma pessoa forte de 18 a 30 anos de idade para ser abatida e depois consumida". O engenheiro Bernd Jürgen Brandes respondeu ao anúncio, e teve seu cadáver consumido por Meiwes durante 10 meses. Meiwes foi condenado à pena de prisão de perpétua.

O horror desta notícia relata, primeiramente, os riscos que as matrizes comunicativas anônimas, especialmente as denominadas redes sociais, trazem para a integridade física e psicológica dos seres humanos (TEUBNER, 2006). É como se a vastidão (virtual) da rede mundial de computadores permitisse um anonimato próprio à liberação dos impulsos que, no convívio social real, são, de um modo geral, tolhidos. Não há o Outro (pelo menos não o Outro visível, ainda que se sabia que os rastros produzidos pelos indivíduos na internet sejam acompanhados por um sem número de pessoas) para frear a pulsão tanática.

Outro exemplo do caráter de fragmentação e mercantilização do ser humano, próprio da contemporaneidade e intensificado pelas redes sociais, também se constata nos casos de jovens que venderam a própria virgindade, em sítios de leilões virtuais. Essa ausência de freios aos desejos e ações aberrantes (pelo menos sob o ponto de vista da moralidade média e da dignidade pertencente a cada ser humano), pode ser vista, também, no hate speech (discurso de ódio), predominante nas redes sociais, em que não há respeito pela opinião alheia, sendo qualquer comentário em sentido contrário ao de cada interlocutor alvo de zombarias, ironias e ofensas raivosas.

Talvez essas iniciativas decorram da influência do mercado sobre a mídia, de modo geral. Analisando os filmes Matrix e 1984, Linhares (2014, p. 36) além de apontar os riscos das teorias utópicas resvalarem para distopias, sublinha os perigos da sociedade digital, subserviente aos objetivos do mercado:

Nos filmes analisados, observamos que para a construção das bases de sustentação e legitimação das relações de poder, as mídias e as tecnologias de informação e comunicação exercem um papel fundamental ao construir 
mostrar a imagem de um mundo perfeito e racional, um projeto único de sociedade, uma única forma de pensar, como se esta fosse consensual. A exemplo da teoria da Agenda Seting ou da teoria do Silêncio (FRANÇA; HOHLFELDT, 2001), através desta demonstração, a mídia amplia as possibilidades de admoestar-nos para além da consumação desta verdade, a defesa desta forma de pensar ou agir como a única possível, como fruto de nossa crítica a legítima forma de pensamento, contribuindo para justificar as muitas formas de poder e sua manutenção, nos regimes despóticos, sanguinários e desumanos, em que uma mídia escrava do poder econômico e/ou político foi sempre usada como instrumento de ratificação e manutenção do poder constituído.

As regras do mercado, no Brasil e no mundo, conformam a infraestrura econômica das nações, ditando, inclusive, limites aos direitos individuais e sociais. Todos os bens públicos (educação, saúde, previdência, segurança) tendem a se tornar commodities, assim como também se permite até mesmo a mercantilização dos direitos da personalidade, outrora vistos como inalienáveis e indisponíveis (CANOTILHO, 2015).

A impressão que se tem, atualmente, é que os direitos fundamentais, no Brasil e no mundo, vêm perdendo força para se sustentar frente ao ideário neoliberal. $\mathrm{O}$ Welfare State, que se tornou modelo a partir de meados do século XX, tem suas bases minadas pelo mainstream da globalização, desde a década de 90 do século passado. Tanto o Estado como o ser humano estão sob a mira do sistema financeiro internacional, que se utiliza das matrizes comunicativas anônimas para impor sua visão de mundo, em que políticas sociais e pessoas ou são comercializáveis ou são descartáveis.

Na mesma linha, Peter Häberle (VALADÉS, 2009, p. 20), ao citar Hegel, para quem, na opinião pública, todo o verdadeiro e o falso se encontram simultaneamente presentes. No dizer do constitucionalista alemão: “As empresas multinacionais estendem um poder econômico quase incontrolável que pode converter-se em poder político. É de se começar com uma constituição pluralista dos meios de comunicação" (VALADÉS, 2009, p. 20).

A predominância do interesse de grandes conglomerados financeiros sobre os direitos fundamentais, intensificado pela utilização manipuladora dos meios de comunicação de massa tradicionais e pelas redes sociais (WhastApp, Facebook, Instagram e Twiter), configura, à toda evidência, um reflexo distópico da sociedade contemporânea. Também o são os ataques da criminalidade organizada (financeira; dos tráficos ilícitos de drogas e pessoas; fundamentalista, como o terrorismo) dirigidos ao Estado e aos indivíduos, sendo que o próprio Estado - que deveria proteger os cidadãos, 
por vezes é cooptado pelos interesses escusos dos denominados criminosos de colarinho branco, vulnerabilizando ainda mais o ser humano.

Resta, então, perguntar, que alternativas são oferecidas à utopia e ao seu duplo, a distopia. No capítulo seguinte, serão apontadas saídas, oriundas da Literatura, da Sociologia e da Filosofia, aos riscos totalitaristas dos não-lugares e dos lugaresdistorcidos.

\title{
4 HETEROTOPIA E RETROTOPIA
}

Uma das alternativas à utopia e à distopia, especialmente para os que se prendem ao viés negativo da utopia (ou como algo irrealizável, ou como caminho para a distopia), é a chamada heterotopia. Na Teoria Literária, Vilas-Boas (2002, p. 100) cita Foucault, para quem, se as utopias apontam para o não realizável, o não-espaço, as heterotopias seriam:

Lugares reais, lugares operantes, que estão inscritos na organização social, por assim dizer anti-espaços ou contrafortes, utopias realizadas verdadeiramente, nas quais os espaços reais dentro das respectivas culturas são simultaneamente representados, contestados ou invertidos, são como espaços fora de todos os espaços, mesmo que possam ser detectados. (Foucault, 1990: 39; trad. minha)

Ainda com Vilas-Boas (2002, p. 100) as heterotopias não são utopias ideais, no sentido de configurarem um locus amoenus ou um espaço alternativo positivo, mas lugares outros, que, pela sua presença, podem, dependendo do receptor, questionar o presente extratextual, subvertê-lo, transgredi-lo, como se transgridem limites. Nas palavras do autor:

\begin{abstract}
Heterotopias e utopias são, pois, de modo diferentes, simulações de um desejo de mundo, ou de receios no caso das distopias. Por isso mesmo, são discursos literários ligados à época em que se inserem, precisamente pelos motivos pelos quais pretendem afastar-se dela. Para os leitores contemporâneos, a contextualização na época da escrita é sempre altamente frutuosa, porque desse modo é possível perceber o que está por trás de cada uma das utopias, distopias ou heterotopias. (VILAS-BOAS, 2002, p. 115).
\end{abstract}

Ora, se, consoante Peter Häberle (VALADÉS, 2009, p. 192-193), a Europa pode ser considerada (para si mesma) uma utopia, para os brasileiros, o modelo de conformação da sociedade europeia pode ser visto como uma heterotopia, isto é, algo verossímil, concretizável. Foi na Europa, seja no período clássico (gregos e romanos), seja nos intercursos modernos e pós-modernos, que os ideais da subjetividade e do respeito à 
dignidade humana encontraram seu solo fértil e se desenvolveram (apesar das quedas homéricas oriundas das duas grandes guerras mundiais, bem como dos regimes totalitários que dominaram o continente europeu em boa parte do século XX). Também a Europa pode ser considerada "espelho" no que tange aos direitos sociais, como educação, saúde, trabalho e previdência.

As heterotopias, no âmbito da Ciência do Direito, devem ser buscadas naquilo que Häberle denominou de quinto método de interpretação. Savigny tornou célebres os métodos gramatical, lógico, histórico e sistemático; Häberle propôs um quinto método, o direito comparado. Conforme o próprio Häberle (VALADÉS, 2009, p. 25):

\footnotetext{
Os Estados constitucionais podem aprender mutuamente com suas experiências. Especialmente na Europa já há uma grande quantidade de exemplos de comunidade de produção e de recepção de assuntos de direitos humanos, que, por meio do direito comparado, funcionaram como quinto método de interpretação, e que, por exemplo, saem ao encontro de forma de princípios gerais de direito.
}

Deste modo, é possível fazer uma associação, pelo menos na seara do Direito, entre heterotopia e direito comparado (inclusive o constitucionalismo multinível), assim como se mostra recomendável verificar modelos de sociedades que, ao adotar a formatação de Estados Democráticos de Direito, permitiram uma diminuição das desigualdades aliada à garantia das liberdades (poderiam ser mencionados, como exemplos de sociedades heterotópicas - pelo menos sob o prisma brasileiro - os países escandinavos, em que há respeito aos direitos sociais e individuais).

Na Teoria Literária é comum, outrossim, a associação entre os idílios (como suspensão do tempo histórico) com as heterotopias. De um modo geral, os idílios projetam-se no passado, confundindo-se, deste modo, com a retrotopia. Retrotopia, por sinal, é nome de uma obra póstuma de Bauman (2017), que a coloca como membro da muito ampla família das relações afetivas com algum "alhures"; i.é, ao lado da própria utopia, da distopia e da heterotopia, a retrotopia tem sido um ingrediente endêmico e inseparável da condição humana, desde o momento da descoberta da possibilidade de escolha nas decisões humanas. Nas palavras do próprio Bauman $(2017$, p. 8) “o mundo aqui e agora nada mais é que um entre um número indefinível de mundos possíveis passados, presentes, futuros". 
Após fazer o alerta de que há o risco desse sentimento de nostalgia, próprio das retrotopias, descambar para o nacionalismo xenófobo, Bauman (2017, p. 8-9) apresenta a retrotopia como uma reafirmação pós-moderna da utopia:

\begin{abstract}
Quinhentos anos depois de Thomas More dar o nome de "Utopia" ao sonho humano milenar de retornar ao paraíso, ou de estabelecer a bem-aventurança na terra, mais uma tríade hegeliana formada por uma dupla negação está hoje perto de fechar seu círculo. Depois que as perspectivas de felicidade humana - amarradas, desde More, a um topos (um lugar fixo, uma polis, uma cidade, um Estado soberano, cada um deles sob um soberano sábio e benevolente) foram descoladas e desamarradas de todo e qualquer topos particular, e individualizadas, privatizadas e personalizadas ("subordinadas" a indivíduos humanos segundo o modelo dos caracóis), agora é a vez de elas serem negadas por aquilo que, de forma arrojada e quase bem-sucedida, tentaram negar. Dessa dupla negação da utopia ao estilo More - sua rejeição seguida por sua ressureição - hoje estão emergindo "retrotopias": visões instaladas num passado perdido/rouboado/abandonado, mas que não morreu, em vez de se ligarem a um futuro "ainda por nascer" e, por isso, inexistente, como foi o caso da sua ancestral duplamente repudiada.
\end{abstract}

Para Bauman (2017, p. 12) "o que eu chamo de retrotopia é um derivativo do já mencionado segundo grau de negação - a negação da negação da utopia”. Complementa Bauman (2017, p. 13): "Fiel ao espírito utópico, a retrotopia deriva seu estímulo da esperança de reconciliar, finalmente, segurança e liberdade, feito que nem a visão original nem sua primeira negação tentaram alcançar - ou, se tentaram, fracassaram". Como exemplos de tendências retrotopistas (negativas), o referido autor apresenta:

\begin{abstract}
A reabilitação do modelo tribal de comunidade; o retorno ao conceito de um eu primordial/prístino predeterminado por fatores não culturais e imunes à cultura; e a retração como um todo da percepção hoje vigente (dominante tanto nas ciências sociais quanto entre as opiniões populares) das características essenciais, presumilvelmente não negociáveis e sine quibus non da "ordem civilizada". (BAUMAN, 2017, p. 13).
\end{abstract}

Pensadores de diversas matizes ideológicas e formações defendem uma espécie de retrotopia (positiva), em substituição à violência e à fragmentação do ser humano, próprias do mundo moderno e pós-moderno. Jorge Forbes, por exemplo, afirma que o futuro hoje é fruto de uma interpretação, uma invenção, e arremata:

O mundo globalizado, não o vejo compor o Um, perfeito, completo, como o concebeu Parmênides. Queria transmitir entre nós a ideia de que há formas não totais, difusas, para pensarmos a atualidade. Estamos no momento em que o processo de fragmentação só pode ser conciliado por meio de pontes culturais. Então, ou viveremos um massacre tecnológico ou um novo renascimento, diferente do anterior, porque não trará a unidade completa em seu horizonte, mas virá simplesmente como um retorno dos valores culturais, para repactuar a sociedade em nova forma. (FORBES, 2005, p. 16). 
Ou seja, Jorge Forbes sugere, como solução às relações líquidas e desbussoladas da contemporaneidade, um retorno aos valores culturais do Renascimento, especialmente o respeito à dignidade imanente de todos os seres humanos. Também Touraine (1994, p. 40), reconhecendo que a razão modernista fracassou em sua utopia de trazer abundância, liberdade e felicidade, sugere uma transmutação do ideário modernista, em um retorno à Renascença:

É preciso voltar incessantemente ao clarão da Renascença e aos primórdios da modernidade (...), para se proteger contra todas as formas de repressão exercidas em nome do Estado, do dinheiro ou da própria razão. A crítica da ideologia modernista não deve conduzir à volta do que ela destruiu.

\section{CONCLUSÕES}

No livro Utopia, Thomas More descreveu uma sociedade em que predominavam a tolerância e a justiça social. Passados mais de 500 anos do lançamento do livro, no presente artigo ressaltaram-se inúmeras ideias de More que se incorporaram nas constituições e nos ordenamentos jurídicos pelo mundo. Aliás, há substancial tendência, mormente no Direito Constitucional, de se associar a noção de Constituição à Utopia, haja vista a forte carga valorativa de seus preceitos, e o seu caráter pretensamente conformador da sociedade.

Por outro lado, verifica-se um enorme descompasso entre as previsões normativas das constituições, convenções e declarações internacionais relativas aos direitos humanos e a realidade de violência, miséria, ódio e preconceito ainda presente em considerável parte do mundo. O oposto (ou duplo) da utopia, isto é, as distopias (cujos exemplos maiores são encontrados na literatura, v.g., de Kafka, Huxley, Orwell, Burgess) longe, portanto, de se mostrarem como hipóteses futurísticas tenebrosas, concretizam-se no Brasil e em muitos países.

Pairando nesse limbo entre um manto protetivo-normativo e a realidade de exclusão social, competição e fragmentação, o ser humano há de buscar um "outro lugar", seja como destino (daí a questão das imigrações), seja como modelo (veja-se o exemplo do quinto método interpretativo de Häberle - direito comparado, especialmente nos direitos fundamentais). Aqui surgem as heterotopias, como alternativas às utopias (que ainda possuem uma conotação negativa) e às distopias. 
Em substituição às utopias (que, em essência, destinam-se ao futuro) também se apresentam as retrotopias (as quais, assim como as utopias, trazem, em si, o gérmen de tendências totalitárias e divisionistas). O retorno aos ideais humanistas, universalistas e fraternais da Renascença é uma das soluções apontadas por pensadores de diversos ramos do conhecimento aos dilemas individuais e coletivos hodiernos.

Atualmente, as sociedades encontram-se diante de desafios (lançados pelo mercado, pela criminalidade organizada e pelo mundo virtual) que colocam em xeque as razões de ser e as funções do Estado. No Brasil, é preciso uma escolha - um ato de vontade - de todos, para que os valores constitucionalmente assegurados, principalmente a dignidade humana, realizem-se na práxis, sob pena do esfacelamento ainda mais severo das pessoas e comunidades, concomitante ao acúmulo indecoroso das riquezas nacionais nas mãos de poucos.

Na tentativa de responder à pergunta do título deste artigo "o que será", inspirada na música de Chico Buarque, afirma-se que o futuro de um ideário de sociedade fraternal, na forma como pensou More, ou como idealizaram os legisladores constituintes, é incerto, mas confiar, ter esperança de que os seres humanos irão se entender e se respeitar é fundamental. É provável, inclusive, que não exista resposta para a indagação, mesmo porque o porvir das utopias constitucionais (e, com elas, dos direitos humanos fundamentais) depende da postura de cada um, no aqui e agora.

Como disse Alves, ao comentar a tela de Clarice Lispector Pássaro azul, (2018, p. 148): "Pássaro azul são traços de liberdade que se articulam como narrativa de direitos humanos, processo de transformação interpessoal. Dessa forma, Clarice conta a narrativa do vôo, mas deixa em aberto o destino do pássaro ao olhar do espectador". Noutras palavras, o destino das utopias, de More à utopia constitucional brasileira, está no conhecimento, na interpretação e na introjeção, como valores inerentes à intersubjetividade, por todos os seres humanos, dos direitos individuais e sociais fundamentais; e, principalmente, nas escolhas e atitudes daqueles que detém o controle do Estado (Poderes Executivo, Legislativo e Judiciário), do sistema financeiro, dos sistemas de produção e da mídia, em prol de respeitá-los e concretizá-los.

As alternativas distópicas/tanáticas ao ideário utópico/constitucional não se mostram desejáveis. Trata-se de uma questão de vida ou morte, ou pelo menos de vida 
com dignidade para uma boa parte da população brasileira e mundial. Nas palavras de Bauman (2017, p. 147): "Mais do que em qualquer tempo, nós - habitantes humanos da Terra - estamos numa situação ou/ou: estamos diante da perspectiva de nos darmos as mãos ou de rumar para as nossas valas comuns".

\section{REFERÊNCIAS}

ABBAGNANO, Nicola. Dicionário de Filosofia. 6. ed. São Paulo: WMF Martins Fontes, 2012.

ALVES, Miriam Coutinho de Faria. Direitos humanos no imaginário artístico de Clarice Lispector: O pássaro da liberdade. Unisul de Fato e de Direito: revista jurídica da Universidade do Sul de Santa Catarina, [S.I.], v. 9, n. 17, p. 141-150, ago 2018. Disponível em: $<$ http://www.portaldeperiodicos.unisul.br/index.php/U_Fato_Direito/article/view/67 4239> Acesso em: 12 dez. 2018.

ANDRADE, Carlos Drummond. José. São Paulo: Companhia das Letras, 2012.

BAUMAN, Zygmunt. Retrotopia. Rio de Janeiro: Jorge Zahar Editor Ltda., 2017.

BOBBIO, Norberto. A era dos direitos. Rio de Janeiro: Elsiever, 2004.

CANOTILHO, José Joaquim Gomes. Conferência de enceramento do XVIII Congresso Internacional de Direito Constitucional. 2015. (1h43m). Disponível em: <https://youtu.be/kXhEUsVbTj8>. Acesso em: 02 de novembro de 2018.

FORBES, Jorge; JÚNIOR, Miguel Reale; JÚNIOR, Tércio Sampaio Ferraz (orgs.). A invenção do futuro: um debate sobre a pós-modernidade e a hipermodernidade. Barueri: Manole, 2005.

GONÇALO VILLAS-BOAS. Utopias, distopias e heterotopias na literatura de expressão alemã. Cadernos de Literatura Comparada 6/7: Utopias, Orgs. Fátima Vieira e Jorge Miguel Bastos da Silva. Porto: Granito/Instituto de Literatura Comparada Margarida Losa, p. 95-118, 2002.

HÄBERLE, Peter. Hermenêutica Constitucional. A sociedade aberta dos intérpretes da constituição: uma contribuição para a interpretação pluralista e "procedimental" da constituição. Tradução de Gilmar Ferreira Mendes. Porto Alegre: Sergio Antonio Fabris Editor, 1997, Reimpressão 2002.

HABERMAS, Jürgen. O discurso filosófico da modernidade: doze lições. Tradução de Luiz Sérgio Repa e Rodnei Nascimento. São Paulo: Martins Fontes, 2000.

HESSE, Konrad. A Força Normativa da Constituição. Porto Alegre: Sérgio Fabris Editor, 1991. 
HILÁRIO, Leomir Cardoso. Teoria Crítica e Literatura: a Distopia como ferramenta de análise radical da modernidade. Anuário Literatura, Florianópolis, v. 18, n. 2, p. 201$215,2013$.

JÚNIOR, Márcio Meirelles Gouvêa. Uma nova tradução da Utopia. Utopia. 1. Ed. Belo Horizonte: Autêntica Editora, 2017.

LINHARES, Ronaldo Nunes. A (com)formação da distopia e do pensamento único da sociedade perfeita em 1984 e Matrix. Sobre os conceitos, os filmes e as referências. Direito e cinema - filmes para discutir conceitos, teorias e métodos. Edufba, p. 23-38, 2014.

MARIANO, Cynara Monteiro. Emenda Constitucional 95/2016 e o teto dos gastos públicos: Brasil de volta ao estado de exceção econômico e ao capitalismo do desastre. Revista de Investigações Constitucionais, Curitiba, vol. 4, n. 1, p. 259-281, jan./abr. 2017.

MATOS, Andityas Soares de Moura Costa. Utopia: passado, presente e futuro de um nãolugar. Variações sobre um tema de Thomas More. Utopia. 1. Ed. Belo Horizonte: Autêntica Editora, 2017.

MEIWES, Armin. In: Wikipédia: a enciclopédia livre. Disponível em: https://pt.wikipedia.org/wiki/Armin_Meiwes. Acesso em: 03 nov de 2018.

MORE, Sir Thomas. Utopia. Tradução de Márcio Meirelles Gouvêa Júnior. 1. Ed. Belo Horizonte: Autêntica Editora, 2017.

ORWELL, George. 1984. Tradução de Alexander Hubner e Heloisa Jahn. São Paulo: Companhia das Letras, 2009.

PAVLISKI, Evanir. 1984: a distopia do indivíduo sob controle [livro digital]. Ponta Grossa: Editora UEPG, 2014.

RICOER, Paul. A ideologia e a utopia. Tradução de Sílvio Rosa Filho e Thiago Martins. 1. Ed. Belo Horizonte: Autêntica Editora, 2015.

ROUDINESCO, Elisabeth; PLON, Michel. Dicionário de psicanálise. Rio de Janeiro: Zahar, 1998.

TEUBNER, Gunther. The Anonymous Matrix: Human Rights Violations by 'Private' Transnational Actors. Modern Law Review, Vol. 69, p. 327-346, 2006. Disponível em: https://core.ac.uk/download/pdf/14503233.pdf. Acesso em: 25 out. 2018.

TOURAINE, Alain. Crítica da Modernidade. Rio de Janeiro: Vozes Ltda., 1994.

VALADÉS, Diego (organizador). Conversas acadêmicas com Peter Häberle. São Paulo: Saraiva, 2009. 